\title{
COMMent
}

\section{Up Squeeze-Out Merger Creek Without a Paddle: Life for Minority Interest Holders After Welch $v$. Via Christi Health Partners, Inc."}

\section{INTRODUCTION}

"Virtues are lost in self-interest as rivers are lost in the sea." maxim is particularly relevant to majority interest holders in noncorporate entities who "lose their virtues in self-interest" by completely removing minority interest holders from an entity. The vehicle typically employed to accomplish this task is the squeeze-out merger. In a squeeze-out merger, minority interest holders receive a cash amount determined by the majority interest holder and are effectively "squeezed out" of ownership in the surviving entity. ${ }^{2}$

Minority shareholders in corporations who object to this process normally can employ one of two protective devices: (1) appraisal rights; or (2) damages stemming from a breach of fiduciary duty. ${ }^{3}$ Although generally incapable of rescinding a squeeze-out merger, these two devices always ensure a judicially determined fair price for the minority shareholder's cashed-out shares.

These rights available in corporate squeeze-out mergers, however, are not as apparent in non-corporate squeeze-out mergers. In Welch $v$.

\footnotetext{
* Francis J. Baalmann. J.D. candidate 2007, University of Kansas School of Law; B.S. 2005, Newman University. I would like to thank Professor Webb Hecker, Mike Breen, Carol Toland, Chase Evans, Gary Atherton, and the Kansas Law Review Staff for their hard work and invaluable contributions to this article. I also would like to thank my wife Rebecca for teaching me how to love, my parents Mark and Diane for teaching me how to live, and my late grandfather Fred Orth for teaching me that success is not measured by how far one gets in life, but rather by how hard one works to get there.

1. Francois VI, Duke de La Rochefoucauld, The Maximes, available at http://www.britannica. com/eb/article-4018 (Translated from French)

2. See, e.g., Hesston Corp. v. Kays, 870 P.2d 17, 20-22 (Kan. 1994) (providing an example of a squeeze-out merger).

3. See infra Part IV.B (discussing corporate fiduciary principles in the context of squeeze-out mergers).
} 
Via Christi Health Partners, Inc. ${ }^{4}$ the Kansas Supreme Court analyzed a squeeze-out merger between a limited partnership and a limited liability company. Squeezed-out limited partners brought suit after the merger claiming the price they received for their cashed-out shares was too low. They attempted to employ the two protective devices normally utilized in corporate squeeze-out mergers to receive a judicially-determined fair price. $^{5}$

After searching through the Mixed Entity Merger statutes, ${ }^{6}$ the Kansas Revised Uniform Limited Partnership Act ("KRULPA") ${ }^{7}$ and the Kansas Uniform Partnership Act ("KUPA"), ${ }^{8}$ the Kansas Supreme Court determined the limited partners were not entitled to appraisal rights." Moreover, the court concluded that Via Christi Health Partners, Inc. ("Via Christi"), the sole general partner of the limited partnership who controlled both entities, did not breach its fiduciary duty to the limited partnership. $^{10}$

Part II of this Comment will begin by briefly summarizing the Kansas Supreme Court's analysis in Welch v. Via Christi Health Partners, Inc. Part III will discuss why the Kansas Supreme Court was correct in concluding the merger orchestrated by Via Christi did not create appraisal rights. Part IV will evaluate the court's fiduciary duty analysis, separating the discussion into four parts: first, an examination of the codified fiduciary duties in section 56a-404 of the Kansas Statutes Annotated; second, an overview of corporate fiduciary principles; third, an application of corporate fiduciary principles to partnership law; and lastly, a determination that Via Christi should have been required to establish a fair merger price under the strict fairness test to avoid breaching its fiduciary duty. This Comment concludes that had Via Christi been required to demonstrate a fair merger price, the squeezedout limited partners would have been ensured a judicially-determined fair price for their cashed-out interests. In other words, a partner in a partnership, like a minority shareholder in a corporation, would be protected should a controlling partner lose his virtues in self-interest.

4. 133 P.3d 122 (Kan. 2006).

5. Id. at $126-27$.

6. KAN. StAT. ANN. $\S \S 17-7701$ to 7708 (1995).

7. Id. $\S \S 56-1 \mathrm{a} 01$ to $1 \mathrm{a} 610$.

8 Id. $\$ \S 56 \mathrm{a}-101$ to 1305 .

9. Welch, 133 P.3d at 144-45.

10. Id. 


\section{Summary OF WELCH V. VIA CHRISTI HEALTH PARTNERS, INC.}

A. Facts of Welch v. Via Christi Health Partners, Inc.

MR Imaging Center, L.P. (“MR Imaging Center"), a medical imaging business, was formed in Kansas on September 17, 1985. ${ }^{11}$ Via Christi served as the sole general partner in MR Imaging Center and held a $71 \%$ ownership interest. ${ }^{12}$ Various doctors held the remainder of the ownership interest. ${ }^{13}$

In 2002, Via Christi embarked on a course it anticipated would lead to the merging of MR Imaging Center into a new entity. ${ }^{14}$ Via Christi enlisted Paragon Health Capital Corporation ("Paragon") to conduct an appraisal of MR Imaging Center. ${ }^{15}$ Additionally, Via Christi "arranged for itself and other persons it selected to acquire the medical imaging business conducted by [MR Imaging Center] through a 'squeeze-out' merger." 16 The other persons Via Christi selected to be part of the merger had strong ties to Via Christi. ${ }^{17}$ For example, the affiliates of the selected persons "had been substantial contributors to the Via Christi Foundation, a charitable affiliate of [Via Christi]."18

Via Christi created a limited liability company, MRI, LLC, for the purpose of consummating the merger. ${ }^{19}$ Via Christi controlled and owned $64.2 \%$ of MRI, LLC. ${ }^{20}$ On July 15, 2003, Via Christi sent the limited partners a "Notice of Special Meeting" of the partners of MR Imaging Center. ${ }^{21}$ This notice provided that the limited partners "would be asked to approve (a) an amendment to the Agreement of Limited Partnership to permit MR Imaging Center[] to merge with 'another general or limited partnership, corporation, or limited liability company,' and (b) the merger agreement between MR Imaging Center[] and MRI, LLC . . . in which Via Christi also held a controlling interest." ${ }^{22}$ The

11. Id.at 125 .

12. $I d$.

13. Id.

14. Brief of Appellants at 2, Welch v. Via Christi Health Partners, Inc., No. 04-92867-A (Kan. Ct. App. Dec. 29, 2004).

15. Welch, 133 P.3d at 126.

16. Brief of Appellants, supra note 14, at 3 .

17. Id.

18. Id.

19. Welch, 133 P.3d at 126 .

20. Id. at 125 .

21. Id.

22. Brief of Appellees at 3, Welch v. Via Christi Health Partners, Inc., 133 P.3d 122 (Kan. 2005) (No. 04-92867-AS). 
notice further stated each partner's interest "would be redeemed for $\$ 78,408$ per unit." 23 At the insistence of Via Christi and its legal counsel, the value determined by Paragon did not take into account minority interest and marketability discounts. ${ }^{24}$ As a result, all partners - majority and minority - would receive the same price for each unit of the limited partnership when the merger occurred. ${ }^{25}$

"On July 31, 2003, the amendment to the partnership agreement and the merger agreement were approved." 26 Only Via Christi voted in favor of the amendment and the merger. ${ }^{27}$ Following the merger, nine limited partners owning approximately $15 \%$ of MR Imaging Center brought suit against MR Imaging Center and Via Christi. ${ }^{28}$ The limited partners sought "enforcement of their [appraisal] rights as dissociated partners and damages for breach of fiduciary duties, including damages for [Via Christi's] undervaluation of the limited partnership for purposes of the merger." 29 An appraiser hired by the plaintiffs valued each unit of the limited partnership at $\$ 111,537 .^{30}$

\section{B. The Kansas Supreme Court's Decision}

\section{The Squeeze-Out Merger Did Not Create Appraisal Rights}

The Kansas Supreme Court first addressed whether the plaintiffs could invoke appraisal rights. The court began its analysis by recognizing that the Mixed Entity Merger statutes contain authority governing mergers between domestic limited partnerships and domestic limited liability companies. ${ }^{31}$ The court concluded that the Mixed Entity Merger statutes do not create appraisal rights. ${ }^{32}$ The plaintiffs, however, contended that the Mixed Entity Merger statutes do not impair appraisal rights provided by KRULPA or KUPA because of section 17-7707(k) of

\footnotetext{
23. Id.

24. See Welch, 133 P.3d at 145 (noting discovery "showed no evidence that Via Christi acted in anything other than an above-board manner").

25. Id.

26. Id. at 126 .

27. Brief of Appellants, supra note 14, at 5-6.

28. Welch, 133 P.3d at $125-26$.

29. Brief of Appellants, supra note 14, at 7.

30. Welch, 133 P.3d at 126.

31. See id. at 129 ("The plaintiffs and the defendants seem to agree that the merger between MR Imaging Center, L.P., and MRI, LLC, is governed by this statutory authority.”).

32. See id. at 130 ("[T]hese statutes do not themselves grant statutory appraisal or buyout rights").
} 
the Kansas Statutes Annotated, ${ }^{33}$ which preserves "any dissenter's appraisal shares or their equivalent rights that may otherwise be available" outside the Mixed Entity Merger statutes. ${ }^{34}$

Via Christi argued the doctrine of independent legal significance precluded a search for appraisal rights outside of the Mixed Entity Merger statutes, but the court determined section 17-7707(k) specifically "preserves any appraisal or equivalent rights which may otherwise be available to the limited partners in this case." 35 Thus, the court shifted its analysis to "whether the provisions of KRULPA or KUPA provide for statutory appraisal or buyout rights to [] limited partner plaintiffs."

With the analysis shifted to KRULPA and KUPA, the plaintiffs argued that the squeeze-out merger caused them to become dissociated, and because their dissociation did not result in dissolution or winding up of the partnership business, they were entitled to appraisal rights under KUPA. $^{37}$ Via Christi countered that "one does not reach or use [KUPA] for dissociation resulting from withdrawal because withdrawal of a limited partner is specifically provided for in [KRULPA]."38 The court rejected Via Christi's argument, finding that "the plaintiffs never sought to withdraw from the limited partnership .... Rather, the question to be resolved under this issue is whether KRULPA provides any appraisal or buyout rights to involuntarily dissociated limited partners of a limited partnership following a merger with a limited liability company." 39 Further, the court stated that section $56-1 \mathrm{a} 604$ provides: "[i]n any case not provided for in [KRULPA], the provisions of [KUPA] and amendments [sic] thereto shall govern." 40 Thus, "the absence of any authority concerning the appraisal rights of an involuntary dissociated partner after a merger requires [the court] to examine the provisions of KUPA . . . ."41

The court's analysis then moved to the following provisions of KUPA: sections 56a-701, 56a-601, and 56a-906(e). Section 56a-701 entitles a "dissociated partner" to statutory appraisal rights. ${ }^{42}$ Section 56a-601 provides a list of events causing a partner's "dissociation,"

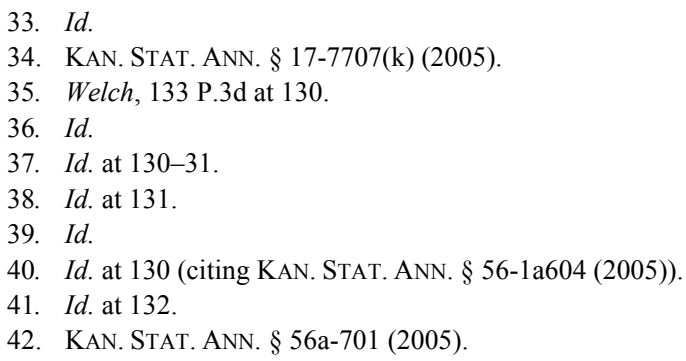


including a partner's expulsion pursuant to the partnership agreement. ${ }^{43}$ The Revised Uniform Partnership Act ("RUPA") Official Comment to section 601 provides: "Section 601 enumerates all of the events that cause a partner's dissociation." ${ }^{\text {"44 }}$ Section 56a-906(e), located under Article 9 Conversions and Mergers, expressly provides that

[a] partner of a party to a merger who does not become a partner of the surviving partnership or limited partnership is dissociated from the entity, of which that partner was a partner, as of the date the merger takes effect. The surviving entity shall cause the partner's interest in the entity to be purchased under K.S.A. 56a-701 ... 45

The court quickly rejected the contention that the squeeze-out merger caused the plaintiffs to be expelled under section 56a-601(c), noting that "expulsion" is not equivalent to a "squeeze-out merger." 46 Additionally, the court stated that no provision in the limited partnership agreement suggested that an expulsion under KUPA took place. ${ }^{47}$

The court next faced an apparent ambiguity between the Official Comment to RUPA 601 and section 56a-906(e). Via Christi asserted that because the Official Comment to RUPA 601 states that "all the events" of a partner's dissociation are covered in RUPA 601, section 56a-906(e) does not create a separate basis for dissociation. ${ }^{48}$ The plaintiffs countered that, despite this comment, the express language of both sections provides otherwise. ${ }^{49}$

While acknowledging the persuasiveness of both parties' arguments, the court decided that section 56a-906(e) did not apply to the current transaction because the provision only pertains to mergers between partnerships in which there is a "surviving partnership or limited partnership." 50 The court emphasized that MRI, LLC survived the merger, which was neither a partnership nor a limited partnership. ${ }^{51}$ Moreover, the court noted that Kansas has not adopted Official Comment 601 of RUPA. ${ }^{52}$ As a result, the court held the plaintiffs could not utilize

\footnotetext{
43. Id. $\S 56 \mathrm{a}-601(\mathrm{c})$.

44. REVISED UNIF. P'SHIP ACT $\S 601 \mathrm{cmt} .1$ (2006).

45. KAN. STAT. ANN. § 56a-906(e) (emphasis added).

46. Welch, 133 P.3d at 133 .

47. Id.

48. Id. at 134

49. Id.

50. Id. at $134-35$.

51. Id. at 135 .

52. Id. at 134
} 
section 56a-701 of KUPA, and thus, the merger did not create appraisal rights. 53

2. The Court Determined Via Christi Did Not Breach Its Fiduciary

Duty to the Limited Partners

The court began its fiduciary duty analysis by citing section 561a253(a) of KRULPA: "Except as provided in this act or in the partnership agreement, a general partner of a limited partnership has the rights and powers and is subject to the restrictions of a partner in a partnership without limited partners." fiduciary duties of a general partner in a limited partnership are found in section $56 a-404$ of KUPA. ${ }^{55}$

Before deciding whether Via Christi had breached its section 56a404 fiduciary duty, the court addressed the parties' arguments involving fiduciary duty and burdens of proof in corporate squeeze-out mergers. The court stated that "before reliance [on corporate burdens of proof and fiduciary duty standards] may be had, accommodation must be made for important differences" between partnerships and corporations. ${ }^{56}$ One important difference noted by the court was that in the corporate context, a member of the board of directors is a "true trustee," while a partner in a partnership is not a "true trustee" because section 56a-404(e) of KUPA "[authorizes] a partner to pursue his or her own interest." 57 Section 56a404(e) of KUPA provides that "[a] partner does not violate a duty or obligation under this [A]ct or under the partnership agreement merely because the partner's conduct furthers the partner's own interest." ${ }^{, 58}$ Based on this distinction coupled with a review of Kansas corporate selfinterest cases, the court determined that "the plaintiffs must establish something above and beyond self-interest or self-dealing in this case involving a limited partnership in order to shift the burden of proof regarding the fairness of the transaction to the defendants." 59 In the court's view, this burden shifting could be accomplished one of two ways: "by establishing a prima facie case of a breach of a fiduciary duty

\footnotetext{
53. Id. at $135-36$.

54. Id. at 136 (citing KAN. STAT. ANN. § 56-1a253(a) (2005)).

55. Id.

56. Id. at 138 .

57. Id. See also id. at 141 (stating that the term "fiduciary duties" in section 56a-404 is misleading "because a partner may legitimately pursue self-interest instead of solely the interest of the partnership and the other partners as must a true trustee").

58. Kan. STAT. ANN. § 56a-404(e) (2005).

59. Welch, 133 P.3d at 139.
} 
under K.S.A. 56a-404 ... [or by] establish[ing] specific acts of fraud, misrepresentation, or other items of misconduct. $" 60$

After determining the parties' fiduciary duties and burdens of proof, the court analyzed whether the plaintiffs had established a prima facie breach of fiduciary duty under section 56a-404. As previously mentioned, the court noted that this provision sets forth the fiduciary duties of a general partner. ${ }^{61}$ Subsection (a) provides that " $[\mathrm{t}] \mathrm{he}$ only fiduciary duties a partner owes to the partnership and the other partners are the duty of loyalty and the duty of care set forth in subsections (b) and (c)." ${ }^{, 62}$ Subsection (b) states:

A partner's duty of loyalty ... is limited to the following: (1) [t]o account to the partnership ... . any property, profit, or benefit derived by the partner in the conduct and winding up of the partnership business or derived from a use by the partner of partnership property ... ; (2) to refrain from dealing with the partnership... on behalf of a party having an interest adverse to the partnership; and (3) to refrain from competing with the partnership in the conduct of the partnership business before the dissolution of the partnership. ${ }^{63}$

The plaintiffs argued Via Christi violated its duty of loyalty under sections 56a-404(b)(1) and (2) "by appropriating the benefits of the partnership business for themselves and for others of their choosing in the merger and by dealing with the partnership as or on behalf of a party ... having an adverse interest to the partnership." ${ }^{\text {, }}$ Via Christi countered that it "did not appropriate the financial returns and benefits of the plaintiffs' interests to itself; rather, its interest in the surviving entity was actually reduced from a $71 \%$ owner of the limited partnership to a $64.2 \%$ owner of the MRI, LLC." 65 To further bolster its argument, Via Christi pointed out that Paragon's appraisal placed the same value on all of the interests in the partnership and that "the plaintiffs erroneously focus[ed] on whether their individual interests were in conflict with or adverse to the defendants, when the statute [section 56a-404] sets forth specific fiduciary duties to the partnership rather than to the individual partners," and that "no evidence was presented that MRI, LLC,

60. Id. at 139 (this standard was originally set forth in Weinberger v. UOP, Inc., 457 A.2d 701, 703 (Del. 1983)).

61. Id. at 136.

62. KAN. StAT. ANN. § 56a-404(a).

63. Id. § 56a-404(b)(1)-(3).

64. Welch, 133 P.3d at 141 .

65. Id. 
competed with or held any interest adverse to MR Imaging Center, L.P., prior to the merger." 66

The court agreed with Via Christi, concluding:

$[\mathrm{N}] \mathrm{o}$ question exists that the interests of the plaintiff limited partners were adverse to both Via Christi and the new investors of MRI, LLC. However, [Via Christi] rightly point[s] out that the question is whether Via Christi acted as or on behalf of a party with an adverse interest to the partnership under this statutory provision. ${ }^{67}$

Additionally, the court held that "the simple fact that MRI, LLC was merging with the limited partnership does not per se establish that its interests were adverse in the absence of any evidence of adversity." 68 As a result, the court concluded the plaintiffs had not established a prima facie breach of fiduciary duty under section 56a-404. ${ }^{69}$

Via Christi also contended that "the plaintiffs ... made no specific allegations of fraud, misrepresentation, or other items of misconduct so as to invoke a judicial inquiry into the fairness of the transaction." ${ }^{, 70}$ The court sided with Via Christi and rejected the plaintiffs' contention that Via Christi's influence over Paragon's evaluation resulted in fraud, noting that "while the evidence established Via Christi may have influenced the appraisal process... it is clear that this influence [resulted] in an increase of $\$ 3.2$ million in the valuation of the limited partnership, which was in the best interest of the limited partners as well as the general partner." ${ }^{71}$ The court also focused on the stipulation of the parties that Paragon would testify it had performed an independent valuation. $^{72}$ As a consequence, the court determined the plaintiffs had not established fraud, misrepresentation, or similar misconduct sufficient to shift the burden of proof to Via Christi. ${ }^{73}$ Having determined that the plaintiffs failed to establish a prima facie breach of fiduciary duty under section 56a-404, or specific acts of fraud, misrepresentation, or similar misconduct, the court concluded that Via Christi had not breached its fiduciary duty as a result of the squeeze-out merger. ${ }^{74}$ 


\section{The Merger Between MR IMAgIng Center, L.P. AND MRI, LLC DiD NOT CREATE APPRAISAL RIGHTS}

The Kansas Supreme Court correctly concluded that the plaintiff limited partners in Welch were not entitled to appraisal rights. An appraisal proceeding is typically a statutory remedy; a party dissenting to a merger is not entitled to appraisal rights under the common law. ${ }^{75}$ As a consequence, the plaintiffs had to locate an applicable statute granting appraisal rights.

\section{A. No Appraisal Rights Exist in the Mixed Entity Merger Statutes}

Both parties asserted that the authority to merge a limited partnership and a limited liability company derives from the Mixed Entity Merger statutes, sections 17-7701 to 17-7708 of the Kansas Statutes Annotated. ${ }^{76}$ Section 17-7703 provides "any ... domestic limited partnerships may merge ... with any one or more persons at least one of which is not a limited partnership, and any... domestic limited liability companies may merge ... with any one or more persons at least one of which is not a limited liability company."77 No provision in the Mixed Entity Merger statutes grants appraisal rights to parties dissenting from a merger to which its provisions apply. ${ }^{78}$ Section $17-7707(\mathrm{k})$, however, states

75. Wichers v. Solomon Valley Feed Lot, Inc., 704 P.2d 383, 385 (Kan. Ct. App. 1985). See also Aspen Advisors LLC v. United Artists Theatre Co., 861 A.2d 1251, 1262 (Del. 2004) ("The Court of Chancery properly held that a statutory appraisal remedy is a narrow statutory right that is available only to stockholders." (emphasis added)); Cede \& Co. v. Technicolor, Inc., 684 A.2d 289, 296 (Del. 1996) (“An appraisal proceeding is a limited statutory remedy." (citing Cede \& Co. v. Technicolor, Inc. 542 A.2d 1182, 1186 (Del. 1988) (emphasis added)); 19 AM. JUR. 2D Corporations $\S 2207$ (2004) ("An appraisal proceeding is a statutory remedy that provides equitable relief to shareholders who dissent from a merger on the ground of the inadequacy of the offering price." (emphasis added)). Appraisal rights can also be created contractually by two parties. See, e.g., KAN. STAT. ANN. $§ 17-7682$ (Supp. 2006) (pertaining to LLC mergers).

76. See KAN. STAT. ANN. § 17-7701(d) ("[A]ny merger or consolidation between ... one or more domestic limited partnerships and any one or more constituent entities at least one of which is not a limited partnership, or one or more domestic limited liability companies and any one or more constituent entities at least one of which is not a limited liability company shall be governed by and subject to the provisions of K.S.A. 17-7701 through 17-7708, and amendments thereto." (emphasis added)); Welch, 133 P.3d at 129 ("The plaintiffs and the defendants seem to agree that the merger between MR Imaging Center, L.P., and MRI, LLC, is governed by [the Mixed Entity Merger statutes].").

77. KAN. StAT. ANN. § 17-7703.

78. See id. $\S 17-7701$ to 7708 (lacking a statutory appraisal right provision); Brief of Appellees, 
"[n]othing in K.S.A. 17-7701 through 17-7708 shall abridge or impair any dissenter's appraisal shares or their equivalent rights that may otherwise be available to the members or shareholders or other holders of an interest, in any constituent entity." $" 79$

Via Christi contended that the doctrine of independent legal significance prevented the plaintiffs from inferring statutory appraisal rights outside of the Mixed Entity Merger statutes. ${ }^{80}$ The thrust of this argument is that the legislature provided statutory appraisal rights in some types of mergers (such as between two partnerships), but did not provide appraisal rights under the Mixed Entity Merger statutes. ${ }^{81}$ This argument ignored the express language of section 17-7707(k) entirely. Because the merger was performed under the Mixed Entity Merger statutes, the entire statutory framework was relevant and had legal significance. The plaintiffs stressed this point in their reply brief to the court, contending that the doctrine of independent legal significance "stands only for the proposition that the mere fact that a transaction cannot be accomplished under one statutory provision does not invalidate it if a different statutory method of consummation exists." 82 The court correctly agreed with the plaintiffs and properly noted that Via Christi indirectly acknowledged this fact when it stated the doctrine "does not preclude looking beyond [The Mixed Entity Merger statutes]... [to] rights that might exist in the operating or merger agreement of a limited liability company under K.S.A. 2005 Supp. 17-7682." 83 Thus, the merger did not create appraisal rights under the Mixed Entity Merger statutes, but section $17-7707(\mathrm{k})$ preserved any rights available in KRULPA or KUPA.

supra note 22, at 14 (acknowledging that the legislature did not create new dissenter's or appraisal rights in the Mixed Entity Merger statutes).

79. KAN. STAT. ANN. § 17-7707(k).

80. Welch, 133 P.3d at 129. See also Brief of Appellees, supra note 22, at 7 ("Just because one may find appraisal rights in one merger statute does not mean those appraisal rights attach to a merger under a different statute.").

81. Welch, 133 P.3d at 129. As the court noted in its opinion, Via Christi "contend[s] it is the prerogative of the legislature to provide appraisal rights for one form of merger but not for another, and each entity merger must comply with the strictures of the authorizing statute and is limited to the remedies found in the authorizing statute." Id.

82. See Reply Br. of Appellants at 2, Welch, 133 P.3d 122 (No. 04-92867-A) (quoting In re Pure Res., Inc., S'holders Litig., 808 A.2d 421, 434 (Del. Ch. 2002)).

83. Welch, 133 P.3d at 130 . 


\section{B. The Merger Did Not Create Appraisal Rights Under the Kansas Revised Uniform Limited Partnership Act}

KRULPA provides that limited partnerships formed on or after January 1, 1984 are governed by its provisions. ${ }^{84}$ Its provisions do not provide appraisal rights. As a consequence, the plaintiffs attempted to get out of KRULPA and employ a provision in KUPA allowing appraisal rights for dissociated partners. Section 56-1a604 of KRULPA provides that "[i]n any case not provided for in the Kansas revised limited partnership act, the provisions of the Kansas uniform partnership act ... shall govern." 85

Via Christi tried to prevent the plaintiffs from using section 56a-601 to get out of KRULPA by contending that the merger caused the limited partners to be dissociated resulting from withdrawal, which is covered in section $56-1 \mathrm{a} 353$ (b) of KRULPA. ${ }^{86}$ The court correctly noted this argument "[was] without merit" because the plaintiffs were not claiming to have withdrawn by the only type of withdrawal permitted by section 56-1a353(b): "at the time or upon the happening of events specified in writing in the partnership agreement. ${ }^{, 87}$ Rather, the plaintiffs asserted that the merger caused them to be involuntarily dissociated from the partnership. Therefore, the court appropriately shifted its analysis to the provisions of KUPA.

84. See Kan. Stat. AnN. § 56-1a603(a) (“All domestic limited partnerships formed on or after January 1, 1984, shall be governed by the provisions of the Kansas revised uniform limited partnership act.").

85. Id. § 56-1a604; see also Temple v. White Lakes Plaza Assocs., 816 P.2d 399, 405 (Kan. Ct. App. 1991) ("RULPA itself provides that for cases not covered by its provisions, the Kansas Uniform Partnership Act . . . should be applied.").

86. Welch, 133 P.3d at 131.

87. Id.; KAN. STAT. ANN. $§ 56-1 \mathrm{a} 353(\mathrm{~b})$. The definition of "withdraw" is "to remove oneself from some activity." RANDOM HOUSE UNABRIDGED DICTIONARY 2183 (2d ed. 1993); see also BLACK'S LAW DICTIONARY 1632 (8th ed. 2004) (defining "withdraw" as "to leave or retire"). Further, the definition of "dissociate" includes "to sever the association of (oneself); separate . . to withdraw from association." RANDOM HOUSE UNABRIDGED DictiONARY 570 (2d ed. 1993) (emphasis added). Additionally, in KUPA, section 56a-601(a) lists as the first example of a way a partner is dissociated as "[a] partnership's having notice of the partner's express will to withdraw as a partner or on a later date specified by the partner." Arguably, if withdrawal is covered in section 56-1a353(b) of KRULPA, and the definition of "dissociation" includes "withdrawal from association," and is listed as a type of dissociation in section 56a-601, one type of dissociation is provided for in KRULPA and section 56-1a604 cannot be used for any type of dissociation. This argument fails to note that the type of withdrawal allowed by the KRULPA provision is narrowly limited to "at the time or upon the happening of events specified in writing in the partnership agreement." KAN. STAT. ANN. § 56-1a353(b). The plaintiffs did not claim to have withdrawn upon an event stated in the partnership agreement. Rather, the plaintiffs claimed they were dissociated involuntarily by merger with a limited liability company, for which KRULPA does not provide. 


\section{The Merger Did Not Create Appraisal Rights Under the Kansas Uniform Partnership Act}

Section 56a-701(i) of KUPA provides statutory appraisal rights for a dissociated partner, and section 56a-601 provides a list of events that cause a partner's dissociation. ${ }^{88}$ Specifically, section 56a-601(c) provides a partner is dissociated from a partnership upon "the partner's expulsion pursuant to the partnership agreement." 89 To fit into section 56a-601(c), the plaintiffs attempted to use the terms "squeeze-out merger" and "expel" synonymously, arguing that the limited partnership agreement was amended by Via Christi for the specific purpose of squeezing out or expelling the plaintiffs. ${ }^{90}$

This argument was flawed because "squeeze-out merger" and "expel" cannot be used interchangeably. KUPA does not define the term "expulsion," but courts and scholars have determined the concept implies that the entity continues to exist after the event. ${ }^{91}$ MR Imaging Center did not continue to exist after the merger. Further, Via Christi correctly noted that if expelling a partner is equivalent to "squeeze out" through a merger, "then it would seem logical for Section 56a-601(c) to crossreference Section 56a-901 [Conversion and Merger] definitions." 92 Thus, the plaintiffs were not expelled under section 56a-601(c) as a result of the merger.

The plaintiffs alternatively contended that they could employ section 56a-701(i) of the Kansas Statutes Annotated because the merger caused them to be dissociated under another provision in KUPA, section 56a906(e). ${ }^{93}$ Article 9 of KUPA is titled "Conversions and Mergers." Section 56a-906(e), located in Article 9, provides, "[a] partner of a party to a merger who does not become a partner of the surviving partnership or limited partnership is dissociated from the entity, of which that partner

88. See KAN. STAT. ANN. § 56a-701(i) ("A dissociated partner may maintain an action against the partnership . . . to determine the buyout price of that partner's interest . . ..”); Id. $\S 56 a-601$.

89. Id. $§ 56 \mathrm{a}-601(\mathrm{c})$.

90. Welch, 133 P.3d at 132-33.

91. See, e.g., Bernard J. Davies, Jr., The Good Faith Principle and the Expulsion Clause in Partnership Law, 33 CONVEYANCE \& PROP. LAW. 32, 40-41 (1969) (stating that the entity must continue to exist); see also Poeta v. Jaffe, No. 1357, 2001 WL 1773885, at *3 (Pa. Com. Pl. Oct. 2, 2001) (discussing that expulsion from a firm implies that the firm continues). Black's Law Dictionary defines the word expel to mean "[t]o drive out or away; to eject, [especially] with force," which implies the object the person is expelled from must continue to exist. BLACK'S LAW DICTIONARY 617 (8th ed. 2004).

92. Brief of Appellees, supra note 22, at 16-17.

93. Welch, 133 P.3d at 133 . 
was a partner, as of the date the merger takes effect." 94 The thrust of the plaintiffs' argument was that section 56a-906(e) creates a separate basis for dissociation, and if a partner is dissociated under this provision, section 56a-701(i)'s granting of appraisal rights for dissociated partners can be utilized. ${ }^{95}$

The plaintiff's argument was technically inapplicable because the limited partners were not "a party to a merger who does not become a partner of the surviving partnership or limited partnership." 96 The entity surviving the merger was a limited liability company, not a partnership or limited partnership. Moreover, section 56a-906 is immediately preceded by section 56a-905, which authorizes mergers only between a partnership and one or more partnerships or limited partnerships. ${ }^{97}$ Likewise, sections 56a-901, 56a-902, and 56a-903 in Article 9 only pertain to partnerships or limited partnerships. ${ }^{98}$ Thus, the placement of section 56a-906(e) in Article 9 along with the language "surviving partnership or limited partnership" leads to the conclusion that the section does not apply to a merger between a limited partnership and a limited liability company when the entity that survives the merger is a limited liability company. ${ }^{99}$

Via Christi argued that section 56a-906(e) does not provide a separate basis for dissociation because section 56a-601 lists the only ways a partner can become dissociated under KUPA. ${ }^{100}$ Via Christi bolstered this argument with language located in an official comment of the Revised Uniform Partnership Act ("RUPA"). ${ }^{101}$ Official Comment 1 to RUPA section 601, section 56a-906(e)'s counterpart, states, "Section 601 enumerates all of the events that cause a partner's dissociation."102

Via Christi's argument failed to consider the importance of the express language in section 56a-906(e) mandating the use of section 56a701. Section 56a-906(e) states that "[t]he surviving entity shall cause the

94. KAN. StAT. ANN. § 56a-906(e).

95. Welch, 133 P.3d at 133.

96. Id. (citing § 56a-906(e)) (emphasis added).

97. KAN. STAT. ANN. § 56a-905.

98. See id. $\S \S 56 a-901$ to 903 (referring only to partnerships and limited partnerships).

99. See Welch, 133 P.3d at 135 ("As the plaintiffs did not and could not argue that the merger in this case occurred under the authority of K.S.A. 56a-905, which deals exclusively with the merger of partnerships, it cannot take advantage of the effect of merger statute, K.S.A. 56a-906(e)."); see also id. at 135 ("An appellate court must consider all of the provisions of a statute in pari materia rather than in isolation, and these provisions must be reconciled, if possible, to make them consistent and harmonious." (citing State v. Legero, 91 P.3d 1216 (Kan. 2004))).

100. Id. at 134 .

101. Id.

102. REVISED UNIF. P'SHIP ACT $\S 601 \mathrm{cmt} .1$ (2006). 
partner's interest in the entity to be purchased under K.S.A. 56a-701."103 The title of section 56a-701 is "[p]urchase of dissociated partner's interest," and every subsection pertaining to the purchase of a partner's interest uses the terminology "dissociated partner," in one form or another. $^{104}$ If section 56a-906(e) does not create a separate basis for dissociation, a partner to whom section 56a-906(e) applies could not utilize any of section 56a-701 because he or she would not be dissociated as the subsections require. This would make the phrase the "surviving entity shall cause the partner's interest in the entity to be purchased under section 56a-701" meaningless. Alternatively, concluding that a partner to whom section 56a-906(e) applies can utilize only the subsections of section 56a-701 pertaining to the buyout of the partner's interest but not employ subsection (i) appraisal rights in the same section would create an absurd result: a partner would be dissociated for some purposes of the section but not for others. Moreover, as the court noted in its analysis, Kansas has not adopted Official Comment 1 to RUPA 601. ${ }^{105}$ Furthermore, section 56a-601 does not contain language indicating the list of dissociation events is an exclusive list. ${ }^{106}$ Most importantly, section 56a-906(e) actually states that the partner "is dissociated." Thus, the conclusion must be reached that section 56a-906(e) creates a separate basis for dissociation but that it could not be utilized by the plaintiffs because the surviving entity was neither a partnership nor a limited partnership.

In summary, the plaintiffs needed to locate an applicable statute granting appraisal rights. The Mixed Entity Merger statutes, KRULPA, and KUPA do not provide appraisal rights for a partner squeezed out in a merger between a limited partnership and a limited liability company. As a result, the court properly concluded that the plaintiffs could not utilize appraisal rights to guarantee a judicially determined fair price.

\section{Via Christi Engaged in SElF-DEAling AND Must Demonstrate A FAIR MERGER PRICE TO AVOID BREACHING ITS FIDUCIARY DUTY}

In addition to appraisal rights, the plaintiffs attempted to obtain a judicially-determined fair price through damages incurred from Via

\footnotetext{
103. KAn. Stat. AnN. § 56a-906(e) (emphasis added).

104. Id. § 56a-701 (emphasis added).

105. See Welch, 133 P.3d at 134 ("Kansas has not specifically adopted the Official Comment to $\S 601 . ”)$.

106. See KAN. STAT. ANN. § 56a-601 (stating "[a] partner is dissociated from a partnership upon the occurrence of any of the following events").
} 
Christi's breach of fiduciary duty. In addressing this issue, the Kansas Supreme Court faced the challenging task of construing statutory provisions codifying a general partner's fiduciary duty, interpreting corporate fiduciary principles, and applying those principles to the merger between MR Imaging Center and MRI, LLC. Unfortunately, the court reached three erroneous conclusions regarding Via Christi's fiduciary duties under section 56a-404 of KUPA. First, the court believed Via Christi only owed a duty of loyalty in section 56a-404(b) to the partnership. ${ }^{107}$ A correct reading of this provision, however, reveals that Via Christi owed a duty of loyalty to both the partnership and other partners. Second, the court determined Via Christi's orchestration of a squeeze-out merger did not violate section 56a-404(b)(2)'s prohibition against acting as or on behalf of a party having an adverse interest to the partnership. ${ }^{108}$ This flawed construction resulted from the court's failure to realize that MRI, LLC clearly had an adverse interest to MR Imaging Center. Finally, the court believed section 56a-404(e) allows a partner to self-deal without breaching any fiduciary duty. ${ }^{109}$ This blunder stemmed from the failure to recognize the distinction between self-dealing and self-interest.

Regarding the interpretation of corporate fiduciary principles, the Kansas Supreme Court misapplied the Weinberger standard by requiring the plaintiffs to demonstrate fraud, misrepresentation, or similar misconduct. Weinberger requires this heightened burden of proof only when the plaintiff is already ensured a judicially determined fair price through appraisal rights.

In a correct fiduciary duty analysis, the heightened burden under Weinberger was inapplicable to the merger in Welch because the plaintiffs could not utilize appraisal rights. As a result, Via Christi had the burden of demonstrating a fair merger price to avoid breaching its fiduciary duty because it engaged in self-dealing, an action prohibited by section 404(b)(2). Thus, the squeezed-out limited partners should have obtained a judicially determined fair merger price in their breach of fiduciary duty claim.

107. Welch, 133 P.3d at 140.

108. Id. at 142 .

109. Id. at 138 . 


\section{A. Section 56a-404 of KUPA Set Forth Via Christi's Fiduciary Duties}

Before delving into the substance of this discussion, it is important to remember the statutory limits of a general partner's fiduciary duty. As discussed in Part III.B, a limited partnership is governed by the provisions of KRULPA, and, where KRULPA is silent, the provisions of KUPA govern by virtue of section 56-1a604 of the Kansas Statutes Annotated. Section 56-1a353(c) of KRULPA provides that a general partner in a limited partnership has the same liabilities to the partnership and other partners as a general partner in a general partnership. ${ }^{110}$ KRULPA, however, fails to specifically address the fiduciary duties of a general partner. As a consequence, sections 56-1a604 and 56-1a253 incorporate the fiduciary duties of a general partner in KUPA.

A general partner's fiduciary duties are codified in section 56a-404 of KUPA. With regard to a general partner's duty of loyalty, section 56a-404(b) provides:

A partner's duty of loyalty to the partnership and the other partners is limited to the following: (1) To account to the partnership and hold as trustee for it any property, profit, or benefit derived by the partner in the conduct and winding up of the partnership business or derived from a use by the partner of partnership property, including the appropriation of a partnership opportunity; (2) to refrain from dealing with the partnership in the conduct or winding up of the partnership business as or on behalf of a party having an interest adverse to the partnership; and (3) to refrain from competing with the partnership in the conduct of the partnership business before the dissolution of the partnership. ${ }^{111}$

Further, section 56a-404(e) states that "[a] partner does not violate a duty or obligation under this act or under the partnership agreement merely because the partner's conduct furthers the partner's own interest." 112

110. KAN. STAT. ANN. § 56-1a353(c).

111. Id. § 56a-404(b).

112. Id. § 56a-404(e). 
1. The Duty of Loyalty in Section 56a-404(b) Is Owed to Both the Partnership and the Other Partners

The Kansas Supreme Court determined that a general partner only owes a duty of loyalty to the partnership by virtue of section 56a404(b). ${ }^{113}$ This conclusion stemmed from the exclusiveness of the language in section 56a-404(b) - "[a] partner's duty of loyalty to the partnership and the other partners is limited to the following"-coupled with the fact that subsections (b)(1), (2), and (3) only mention "the partnership." "114

The court's statutory construction, however, confuses to whom the duty is owed and what the duty actually is. Subsections (b)(1), (2), and (3) of section 56a-404 detail what a general partner's duty of loyalty is. These subsections do not specify to whom the duty of loyalty is owed. The pertinent phrases specifying to whom the duty of loyalty is owed are found in the first sentences of both subsection 56a-404(a) and (b), the former stating " $[\mathrm{t}] \mathrm{he}$ only fiduciary duties a partner owes to the partnership and the other partners are the duty of loyalty and the duty of care," and the latter providing "[a] partner's duty of loyalty to the partnership and the other partners is limited to the following." 115 Moreover, the phrase "is limited to the following" is limiting what subsequently follows, subsections (b)(1), (2), and (3), not the preceding portion of the sentence stating to whom the duty of loyalty is owed.

Similar phraseology in section 56a-404(c), which codifies a general partner's duty of care, bolsters this conclusion. Section 56a-404(c) provides: "[a] partner's duty of care to the partnership and the other partners in the conduct and winding up of the partnership business is limited to refraining from engaging in grossly negligent or reckless conduct, intentional misconduct, or a knowing violation of law."116 The duty of care is owed to both partners and the partnership, while refraining from engaging in grossly negligent or reckless conduct, intentional misconduct, or a knowing violation of law is what the duty is actually limited to. Therefore, a careful reading of subsections 56a-

\footnotetext{
113. Welch, 133 P.3d at 142.

114. KAN. StAT. ANN. § 56a-404(b)(emphasis added); Welch, 133 P.3d at 140.

115. Kan. Stat. AnN. § 56a-404(a), (b) (emphasis added). Although the duties in (b)(1), (2), and (3) discuss interactions only with the partnership, these duties are owed to both the other partners and the partnership by virtue of the first sentence in section 56a-404(b). If the RUPA drafters intended that the duty of loyalty only apply to the partnership, the words "a duty to the partnership to" could have been added at the beginning of (b)(1), (2), and (3).

116. Id. § 56a-404(c) (emphasis added).
} 
404(a) and (b), coupled with similar language in subsection (c) reveals that a general partner's duty of loyalty in subsection (b) is owed to both the partnership and other partners.

\section{Orchestrating a Squeeze-Out Merger and Engaging in Self-Dealing} Are Both Prohibited by Section 56a-404(b)(2)

The Kansas Supreme Court concluded that a general partner's orchestration of a squeeze-out merger does not create a prima facie breach of fiduciary duty under section 56a-404(b)(2) of the Kansas Statutes Annotated. ${ }^{117}$ This section encompasses the prohibition against "dealing with the partnership ... as or on behalf of a party having an interest adverse to the partnership" in the duty of loyalty. ${ }^{118}$ The court believed "the simple fact that MRI, LLC was merging with the limited partnership does not per se establish that its interests were adverse in the absence of any evidence of adversity." "The court restricted its definition of adverseness to categories such as "competition" or "appropriating business." 120

The interests of MRI, LLC, however, were completely adverse to the interests of MR Imaging Center. MR Imaging Center's interests in the merger can only be described as a bargain for the highest and best available price for the partnership and the other partners, while MRI, LLC's interests in the merger can only be described as a bargain for the lowest price possible. These two interests are clearly adverse to each other. Further, courts have repeatedly determined that parties on opposite sides of a merger are adverse to each other. ${ }^{121}$ It is simple fact that a general partner who orchestrates a squeeze-out merger does create

117. Welch, 133 P.3d at 143 .

118. KAN. STAT. ANN. § 56a-404(b)(2).

119. Welch, 133 P.3d at 143

120. Id

121. See Carlyle Towers Condo. Ass'n v. Crossland Sav., FSB, 944 F. Supp. 341, 346 (D.N.J. 1996) (stating conflict arose when law firm's representation of plaintiff became adverse to interests of parent corporation of subsidiary that firm represented in transactional matter, due to merger of parent with defendant); Zirn v. VLI Corp., No. 9488, 1990 WL 119685, at *8 (Del. Ch. 1990) ("Communications between VLI Corporation and American Home ... prior to the execution of the original merger agreement ... cannot be privileged ... because the companies clearly had adverse interests ...."), rev'd on other grounds, 621 A.2d 773 (Del. 1993); George D. Reycraft, Conflicts of Interest and Effective Representation: The Dilemma of Corporate Counsel, 39 HASTINGS L.J. 605, 607 (1988) (noting "the [mergers and acquisitions] specialty firm inevitably faces frequent and recurring conflicts of interest between present and former clients with adverse or potentially adverse interests"); Susan P. Shapiro, Bushwhacking the Ethical High Road: Conflict of Interest in the Practice of Law and Real Life, 28 LAw \& Soc. INQUIRY 87, 175 (2003) ("Accounting firms routinely represent clients with adverse interests, for example, both sides in a corporate merger."). 
a prima facie breach of fiduciary duty under section 56a-404(b)(2), because the parties to the transaction have adverse interests.

Additionally, a prima facie breach of fiduciary duty under section 56a-404(b)(2) will always occur if a general partner engages in selfdealing. Official Comment 2 to RUPA section 404, a section the Kansas Legislature adopted verbatim in section 56a-404(b)(2), states that its provisions "[are] derived from Sections 389 and 391 of the Restatement (Second) of Agency." " Section 389 of the Restatement (Second) of Agency provides that "an agent is subject to a duty not to deal with his principal as an adverse party in a transaction connected with his agency without the principal's knowledge."123 The comment to section 389 further notes that the rule in section 389 is applicable to transactions in which the agent self-deals. ${ }^{124}$ If section 389 of the Restatement (Second) of Agency is applicable to self-dealing transactions, and RUPA section 404(b)(2) is derived from and contains similar language to section 389, then any self-dealing by a partner establishes a prima facie breach of section 56a-404(b)(2). This conclusion is bolstered by another comment to RUPA section 404. Comment 2 states:

[C]omment $\mathrm{c}$ to section 389 explains that the rule [in 404(b)(2)] is not based upon the harm caused to the principal, but upon avoiding $a$ conflict of opposing interests in the mind of an agent whose duty is to act for the benefit of his principal. The most obvious example of when a conflict of opposing interests arises is when self-dealing is present because the partner is acting for both the partnership and him or herself. ${ }^{125}$

The Kansas Supreme Court paraphrases this comment at page 142 of the opinion, but obviously fails to understand its meaning. Immediately preceding the paraphrase the court states "no evidence was presented that Via Christi itself possessed adverse interests to the limited partnership, nor was there evidence that its presence on both sides of the transaction actually harmed the limited partnership in any way." "The court should

122. REVISED UNIF. P'SHIP ACT $\$ 404 \mathrm{cmt} .2$ (2006).

123. RESTATEMENT (SECOND) OF AGENCY $§ 389$ (1957) (emphasis added).

124. Id. at cmt. a. ("This section applies to transactions which the agent conducts for his principal, dealing therein with himself, and also to transactions in which the agent deals with his principal, who acts in person or through another agent; it is applicable to transactions in which the agent is acting entirely for himself and to those in which he has such a substantial interest that it reasonably might affect his judgment."); see also RESTATEMENT (SECOND) OF AGENCY § 391 (1957) ("Unless otherwise agreed, an agent is subject to a duty to his principal not to act on behalf of an adverse party in a transaction connected with his agency without the principal's knowledge.”).

125. REVISED UNIF. P'SHIP ACT $\S 404 \mathrm{cmt} .2$ (emphasis added).

126. Welch v. Via Christi Health Partners, Inc., 133 P.3d 122, 142 (Kan. 2006). 
have concluded that the harm caused to the limited partnership was irrelevant, and that a prima facie breach of fiduciary duty under section 56a-404(b)(2) always occurs if a general partner engages in self-dealing.

3. Section 56a-404(e) Allows Conduct Furthering a Partner's Own Interest but Does Not Trump K.S.A. 56a-404(b)(2)'s Prohibition of Self-Dealing

Before discussing the breadth of section 56a-404(e), the distinction between self-interest and self-dealing must be established. An individual acts in his own self-interest when engaging in a course of conduct from which he derives some personal benefit. By contrast, self-dealing occurs when an individual, by virtue of his dominion over an entity, causes the entity to act in such a way that the individual inures some personal benefit from the entity to the exclusion of others in the entity. The flagship case discussing this distinction is Sinclair Oil Corp. v. Levien ${ }^{127}$ ("Sinclair"), a case in which the Delaware Supreme Court contrasted self-dealing and self-interest using two dividend transactions. The first dividend transaction, the one at issue in the case, involved a controlling shareholder strapped for cash who caused a subsidiary corporation to declare a large cash dividend to all the shareholders. The second dividend transaction, a hypothetical transaction posed by the court, involved a controlling shareholder compelling a corporation to declare a dividend only on class A shares of stock owned by the controlling shareholder, while other shareholders who owned class B stock received no dividends. With regard to both transactions, self-interest existed because the controlling shareholder was compelling the corporation to declare a large cash dividend to further his own personal interests. Selfdealing, however, is present only in the second transaction. In the first transaction, no self-dealing exists because the controlling shareholder does not receive something to the exclusion of the other shareholders; i.e., the minority shareholders receive a proportionate share of the cash dividend. ${ }^{128}$ In the second transaction, however, self-dealing is present because the controlling shareholder receives a large cash dividend to the exclusion of the shareholders who do not own class A stock. ${ }^{129}$ These two dividend transactions reveal that all self-dealing transactions involve some aspect of self-interest, but not all self-interested transactions involve self-dealing. In other words, the two terms are not synonymous.

127. 280 A.2d 717 (Del. 1971).

128. Id. at 721-22.

129. Id. at 721 . 
With the distinction between self-interest and self-dealing in mind, section 56a-404(e) of the Kansas Statutes Annotated can be examined. Section 56a-404(e) provides that "[a] partner does not violate a duty or obligation under this act or under the partnership agreement merely because the partner's conduct furthers the partner's own interest."130 The Kansas Supreme Court in Welch interpreted this provision broadly to include not only self-interested transactions, but also self-dealing transactions. The court stated, "while self-dealing is clearly present in this case, it is important to recognize the distinction under the KUPA statute providing that pursuing one's own self-interest is not per se a breach of a fiduciary duty."131 By adopting this rationale, the Kansas Supreme Court must have concluded either that self-interest and selfdealing are synonymous terms or that because a self-dealing transaction involves self-interest and section 56a-404(e) allows the pursuit of selfinterest, section 56a-404(e) also must allow a partner to engage in selfdealing.

Other courts that have addressed whether RUPA section 404(e) (adopted verbatim in section 56a-404(e) of the Kansas Statutes Annotated) encompasses both self-dealing and self-interest have concluded that RUPA section 404(e) does not authorize a partner to engage in self-dealing. ${ }^{132}$ For example, in Enea v. Superior Court ${ }^{133}$ the California Court of Appeals decided an action brought by a partner in a partnership that owned office rental property. The action alleged that two partners who occupied an office building owned by the partnership were paying rent to the partnership below the fair market rent. ${ }^{134}$ The two partners, while acknowledging the presence of self-dealing, contended that RUPA section 404(e) nonetheless permitted the rental of partnership property to partners below market rates. ${ }^{135}$ Adamantly rejecting this contention, the California Court of Appeals declared, "[RUPA 404(e)] did not empower [the self-dealing partners] to occupy partnership property for their own exclusive benefit at partnership expense ...."136 Rather, the purpose of this provision is to excuse a partner from engaging in a transaction which " merely" further[s] [the

\footnotetext{
130. KAn. Stat. ANN. § 56a-404(e) (2005).

131. Welch, 133 P.3d at 138 .

132. Two recent cases discussing this issue are Enea v. Superior Court, 34 Cal. Rptr. 3d 513 (2005) and In re Textainer P'ship Sec. Litig., No. C-05-0969, 2005 WL 3801596 (N.D. Cal. Dec. 12, 2005).

133. Enea, 34 Cal. Rptr. 3d at 513.

134. Id. at 515 .

135. Id. at 518 .

136. Id. (emphasis added).
} 
partner's] own interests" but does not deprive the partnership of valuable assets. ${ }^{137}$ In other words, RUPA section 404(e) does not authorize a partner to engage in self-dealing.

The Kansas Supreme Court in Welch incorrectly concluded that section 56a-404(e) of the Kansas Statutes Annotated allows both selfinterest and self-dealing. ${ }^{138}$ This section only states that a "partner does not violate a duty" under KUPA "merely because the partner's conduct furthers the partner's own interest." 139 An example is provided in Comment 5 of RUPA section 404(e): "A partner who, with consent, owns a shopping center may, under subsection (e), legitimately vote against a proposal by the partnership to open a competing shopping center." 140 In this example, the partner is not self-dealing because he or she is not causing the partnership to act in such a way that the partner receives some personal benefit to the exclusion of the other partners in the partnership. Rather, the partner is merely acting in his or her own self-interest, voting against a proposal that could potentially have a detrimental effect on the shopping center he currently owns. ${ }^{141}$ The drafters of RUPA undoubtedly created RUPA section 404(e) to ensure that partners are not held to the standard of a "true trustee" and to negate the abundance of case law holding a partner in a partnership to a higher duty than a director of a corporation. No evidence exists, however, that the RUPA drafters envisioned that RUPA section 404(e) authorizes a partner to engage in self-dealing to the detriment of other partners and the partnership. ${ }^{142}$

Further, as a cardinal rule of statutory construction, statutory provisions should be construed to complement rather than conflict with each other. Section 56a-404(b)(2) of the Kansas Statutes Annotated forbids self-dealing by requiring a partner to refrain from dealing with the partnership as a party having an adverse interest to the partnership. If section 56a-404(e) is broadened to authorize self-dealing, these two provisions would conflict. The proper construction - that section 56a404 prohibits self-dealing-avoids conflicting provisions and limits section 56a-404(e) to what it expressly states: a partner does not commit

\footnotetext{
137. Id.

138. Welch v. Via Christi Health Partners, Inc., 133 P.3d 122 (Kan. 2006).

139. KAN. StAT. ANN. § 56a-404(e) (2005).

140. REVISED UNIF. P'SHIP ACT $\S 404$ (e) cmt. 5 (2006).

141. No problem exists under section 56a-404(b)(3) with owning the other shopping center because the other partners consented, as is their privilege under section 56a-103(b)(3)(ii).

142. The Kansas Supreme Court believed pursuing self-interest was not a per se breach. Welch, 133 P.3d at 138 . While a fair reading of section 56a-404(e), this does not mean that self-dealing is not a prima facie breach.
} 
a breach of fiduciary duty merely by pursuing his or her own selfinterest.

By extending the breadth of section 56a-404(e) to include selfdealing transactions, the Kansas Supreme Court's decision has the practical effect of repealing the traditional notion of the duty of loyalty. Traditionally, the duty of loyalty requires that a party "demonstrate [his or her] utmost good faith and the most scrupulous inherent fairness of the bargain" when engaging in a self-dealing transaction. ${ }^{143}$ This "strict fairness" test protects minority interest holders from the controlling party who has the ability to "unilaterally implement transactions to the detriment of minority [interest holders]."144 But following the Kansas Supreme Court's decision in Welch, demonstrating a partner engaged in self-dealing alone will not invoke the strict fairness test. Rather, the party defending the transaction will still be afforded the protections of the more lenient "business judgment rule" despite the fact that selfdealing is present. As a result, the Kansas Supreme Court's decision has the practical effect of annulling a partner's duty of loyalty.

\section{B. Corporate Fiduciary Duty Principles}

Under corporate law, the term "fiduciary duty" encompasses both the duty of care and the duty of loyalty. ${ }^{145}$ To determine whether a decision has caused a breach of either duty, courts use a standard of review called the business judgment rule. The business judgment rule is an evidentiary presumption created to protect decisions that are "'on an informed basis, in good faith, and in the honest belief that the action taken was in the best interests of the company." "146 The rule is designed to protect decisionmakers, and courts generally will not second guess judgments subject to the business judgment rule. ${ }^{147}$ When a decision is challenged, the initial

143. Nixon v. Blackwell, 626 A.2d 1366, 1376 (Del. 1993) (citing Weinberger v. UOP, Inc., 457 A.2d 701, 710 (Del. 1983)).

144. Richard T. Hossfeld, Short-Form Mergers After Glassman v. Unocal Exploration Corp.: Time to Reform Appraisal, 53 DuKE L.J. 1337, 1343 (2004) (citing Bradley R. Aronstam et al., Delaware's Going-Private Dilemma: Fostering Protections for Minority Shareholders in the Wake of Siliconix and Unocal Exploration, 58 Bus. LAW. 519, 520 (2003)). A discussion of how the strict fairness test protects minority interest holders appears later in this Comment.

145. See, e.g., Sandra K. Miller, What Remedies Should Be Made Available to the Dissatisfied Participant in a Limited Liability Company?, 44 AM. U. L. REV. 465, 494 (1994) (discussing the "corporate standards of conduct").

146. Brehm v. Eisner, 906 A.2d 27, 52 (Del. 2006) (quoting Aronson v. Lewis, 473 A.2d 805, 812 (Del. 1984)), overruled on other grounds by Brehm v. Eisner, 746 A.2d 244 (Del. 2000).

147. See Beard v. Elster, 160 A.2d 731, 738 (Del. 1960) ("[W]e find ourselves in the twilight zone where reasonable businessmen, fully informed, might differ. We think, therefore, we are precluded from substituting our uninformed opinion for that of experienced business managers of a 
burden is placed upon the plaintiff to rebut the presumption of the business judgment rule by showing that in fact the decision-maker did not make the challenged decision "'on an informed basis, in good faith, and in the honest belief that the action taken was in the best interests of the company." "148 One way to accomplish this task is to prove the existence of self-dealing. ${ }^{149}$

Rebutting the presumption of the business judgment rule-by, for example, proving the existence of self-dealing - does not automatically invalidate a transaction. ${ }^{150}$ Rather, the burden shifts to the decisionmaker. With the burden shifted, the decision-maker can travel down one of two avenues. First, the decision-maker can "demonstrate [his or her] utmost good faith and the most scrupulous inherent fairness of the bargain." 151 Second, the decision-maker can show that a majority of disinterested directors approved the transaction. ${ }^{152}$

corporation ....").

148. Constance Frisby Fain, Corporate Director and Officer Liability, 18 U. ARK. LiTTLE Rock L.J. 417, 422 (1996) (quoting Aronson, 473 A.2d at 812).

149. See Aronson, 473 A.2d at 812 (stating that directors wishing to use the protections of the business judgment rule "can neither appear on both sides of a transaction nor expect to derive any personal financial benefit from it in the sense of self-dealing, as opposed to a benefit which devolves upon the corporation or all stockholders generally"); Sinclair Oil Corp. v. Levien, 280 A.2d 717, 720 (Del. 1971) (holding that a parent corporation self-dealing through its subsidiary cannot use protections of the business judgment rule); see also Janet E. Kerr, Delaware Goes Shopping for a "New" Interpretation of the Revlon Standard: The Effect of the QVC Decision on Strategic Mergers, 58 ALB. L. REV. 609, 614 (1995) ("Consequently, the plaintiff must rebut this presumption, one way of which is to show a breach of the directors' duty of loyalty.").

150. See Cinerama, Inc. v. Technicolor, Inc., 663 A.2d 1156, 1162 (Del. 1995) ("Burden shifting does not create per se liability on the part of the directors."); Liston v. Gottesegen, 348 F.3d 294, 303 (1st Cir. 2003) ("[A] corporate fiduciary is not entirely barred from ... entering into a selfdealing transaction."); see also DEL. CODE ANN. tit. 8, § 144(a) (2006) (stating that "[n]o contract or transaction between a corporation and 1 or more of its directors or officers, or between a corporation and any other corporation, partnership, association, or other organization in which 1 or more of its directors or officers, are directors or officers, or have a financial interest, shall be void or voidable solely for this reason" (emphasis added)).

151. Nixon v. Blackwell, 626 A.2d 1366, 1376 (Del. 1993) (quoting Weinberger v. UOP, Inc., 457 A.2d 701, 710 (Del. 1983)). The entire fairness test protects minority shareholder directors who have the ability to "unilaterally implement transactions to the detriment of minority shareholders." Hossfeld, supra note 144, at 1343.

152. Benihana of Tokyo, Inc. v. Benihana, Inc., 906 A.2d 114, 120 (Del. 2006) ("Section 144 of the Delaware General Corporation Law provides a safe harbor for interested transactions, like this one, if ' $[t]$ he material facts as to the director's ... relationship or interest and as to the contract or transaction are disclosed or are known to the board of directors ... and the board ... in good faith authorizes the contract or transaction by the affirmative votes of a majority of the disinterested directors ....' After approval by disinterested directors, courts review the interested transaction under the business judgment rule, which 'is a presumption that in making a business decision, the directors of a corporation acted on an informed basis, in good faith and in the honest belief that the action taken was in the best interest of the company." (quoting DEL. CODE ANN. tit. 8, § 144(a)(1) (2006); Aronson v. Lewis, 473 A.2d 805, 812 (Del. 1984) (citations omitted)). 
In Weinberger v. UOP, Inc., ${ }^{153}$ the Supreme Court of Delaware analyzed a squeeze-out merger orchestrated by a controlling shareholder to eliminate minority shareholders. ${ }^{154}$ The court stated that generally, " $[t]$ he requirement of fairness is unflinching in its demand that where one stands on both sides of a transaction, he has the burden of establishing its entire fairness, sufficient to pass the test of careful scrutiny by the courts." 155 The court, however, deviated from the typical corporate fiduciary principles. The court concluded that even if self-dealing can be established, a minority shareholder entitled to appraisal rights must show fraud, misrepresentation, or similar misconduct to establish that the majority shareholder breached its fiduciary duty. ${ }^{156}$ The rationale for this deviation becomes apparent upon the realization that the typical remedy afforded in both an appraisal proceeding and a breach of fiduciary duty claim is a judicially determined fair price for the cashed-out shares. If a judicially determined fair price is already ensured by the availability of an appraisal proceeding, performing a fiduciary duty analysis which only yields the same remedy has no utility.

The Weinberger court also recognized that a squeezed-out minority shareholder may desire an atypical equitable remedy, such as rescission, in a breach of fiduciary duty claim. The court acknowledged that a judicially determined fair price might not always be an adequate remedy and an equitable remedy may be appropriate in some circumstances. ${ }^{157}$ In order to be entitled to an equitable remedy, however, the court determined that the burden remained on the plaintiff to establish fraud, misrepresentation, or similar misconduct: "[u]nder such circumstances, the Chancellor's powers are complete to fashion any form of equitable and monetary relief as may be appropriate, including rescissory damages." $" 158$

After reviewing Weinberger, the Kansas Supreme Court determined that the plaintiffs had the burden to show fraud, misrepresentation, or similar misconduct in the breach of fiduciary duty claim. ${ }^{159}$ This determination ignored the very rationale behind deviating from the

153. 457 A.2d 701 (Del. 1983).

154. Id. at 704-06.

155. Id. at 710 (citation omitted).

156. Id. at 714. The court also stated the minority shareholder's remedy in a cash-out merger "ordinarily should be confined to the more liberalized appraisal proceeding." Id.

157. The court noted that "[t]he appraisal remedy we approve may not be adequate in certain cases, particularly where fraud, misrepresentation, self-dealing, deliberate waste of corporate assets, or gross and palpable overreaching are involved." Id. at 714 .

158. Id.

159. Welch v. Via Christi Health Partners, Inc., 133 P.3d 122, 139 (Kan. 2006). 
traditional controlling shareholder fiduciary duty analysis: a judicially determined fair price is already ensured by the availability of appraisal rights. In this case, the Kansas Supreme Court correctly concluded the plaintiffs were not entitled to appraisal rights. As a result, the Kansas Supreme Court should not have invoked the heightened burden in Weinberger. The plaintiffs, who were not entitled to appraisal rights, were only seeking a judicially determined fair price, not equitable relief, for Via Christi's breach of fiduciary duty. ${ }^{160}$

\section{Application of Corporate Fiduciary Principles to a General Partner Orchestrating a Squeeze-Out Merger}

Applying corporate merger fiduciary principles to the squeeze-out merger in Welch, the original burden of proof should have been placed on the plaintiff limited partners to establish that Via Christi engaged in self-dealing in orchestrating the squeeze-out merger. The exclusive language in section 56a-404 of the Kansas Statutes Annotated, limiting a general partner's duties, does not impede the application of this principle. Self-dealing is prohibited, and the mere act of being on both sides of a merger is self-dealing and literally within the prohibition of section 56a404(b)(2). If limited partners can establish self-dealing in a squeeze-out merger but are not entitled to appraisal rights, application of controlling shareholder principles mandates that the burden shift to the self-dealing general partner to establish that the limited partners received a fair value for their interests in the partnership. Alternatively, the general partner can avoid breach of fiduciary duty by showing all the disinterested partners approved the transaction. ${ }^{161}$

The apparent absolute prohibition on self-dealing in section 56a-404 may seem at first glance to present an obstacle to allowing Via Christi to validate a self-dealing transaction by demonstrating a fair merger price. As previously mentioned, section 56a-404 codifies a partner's fiduciary duty not to engage in certain conduct but does not address whether a partner who engages in prohibited conduct has the ability to validate the transaction and avoid a breach of fiduciary duty. Allowing validation of

\footnotetext{
160. The Kansas Supreme Court also overemphasized a stipulation by the parties regarding the appraiser Paragon. The stipulation only stated that the parties agreed that if Paragon were to testify, Paragon would state that it had engaged in an independent valuation. The stipulation did not provide that Paragon actually engaged in an independent valuation. In fact, the plaintiffs had commissioned their own evaluation, which yielded a much larger cash price for the merger. This second evaluation suggests Paragon might not have actually performed an independent valuation.

161. The default rule under section 56a-103(b)(3)(ii) is that the vote of all the disinterested partners must approve the transactions, unless the partnership agreement provides otherwise.
} 
the transaction and the avoidance of a breach of fiduciary duty is in accord with Professor Edwin Hecker's prediction of how courts should handle a breach of fiduciary duty claim under section 56a-404: "[a]1though stated as absolute prohibitions, these rules probably will be construed to merit validation of conduct that otherwise technically would violate the duty of loyalty if the partner carries the burden of proving good faith and the fairness of the challenged conduct." ${ }^{162}$ Moreover, the belief that the conduct in section 56a-404 is not absolutely prohibited is bolstered by contrasting RUPA section 404(b)(3) with the example in Comment 5 of RUPA section 404. RUPA section 404(b)(3), like section 56a-404(b)(3) of the Kansas Statutes Annotated, states that a partner's duty of loyalty includes the duty "to refrain from competing with the partnership in the conduct of the partnership business before the dissolution of the partnership." The example in Comment 5 of RUPA, however, states, "[A] partner who, with consent, owns a shopping center may, under subsection (e), legitimately vote against a proposal by the partnership to open a competing shopping center."163 By allowing the partner with consent to compete with the partnership, an action prohibited in section 56a-404(b)(3), the RUPA drafters acknowledged that engaging in a prohibited activity under section 404 does not automatically establish a breach of loyalty. ${ }^{164}$

Continuing the application of corporate fiduciary principles, if appraisal rights are not available to the plaintiffs, self-dealing alone shifts the burden and invokes the strict fairness test. If appraisal rights are available to the plaintiffs, Weinberger instructs that a breach of fiduciary duty will only occur if fraud, misrepresentation, or similar misconduct is shown.

My application of corporate fiduciary principles to mergers involving a partnership will further the goals of consistency and elevate substance over form. If a merger occurs between two limited partnerships, or a general and a limited partnership, the cashed-out limited partners get a judicially-determined fair price under sections 56a906(e) and 56a-701. If the general partner attempts to avoid these statutory appraisal rights by utilizing a limited liability company in the merger, my interpretation of section 56a-404 and corporate merger principles yields the same result: a judicially-determined fair price is

162. Edwin J. Hecker Jr., The Kansas Revised Uniform Partnership Act, 68 J. KAN. B. Assoc. 16, 32 (1999) (emphasis added).

163. REVISED UnIF. P'SHIP ACT $\S 404 \mathrm{cmt} .5$ (2006) (emphasis added).

164. See KAN. STAT. ANN. §56a-103(b)(3)(ii) (2005) (explicitly authorizing this type of conduct). 
ensured by requiring the self-dealing partner to demonstrate a fair merger price in court.

\section{The Court Should Have Required Via Christi to Demonstrate a Fair Merger Price Under the Strict Fairness Test to Avoid Breaching Its Fiduciary Duty}

The plaintiff limited partners had the burden of overcoming the business judgment rule by establishing that the general partner, Via Christi, engaged in self-dealing, an act prohibited by section 56a404(b)(2). At first glance, the merger may appear analogous to the first dividend transaction in Singer because the plaintiff limited partners and Via Christi received the same value for their interests in the limited partnership. If all partners received the same amount for their shares, Via Christi arguably did not engage in self-dealing because it did not receive some personal benefit to the exclusion of the other partners in the limited partnership. This argument, however, rings hollow because Via Christi did derive personal benefit from the merger to the exclusion of the limited partners. This benefit did not take the form of a larger merger price per share, but rather, was the continued ownership in the surviving entity, MRI, LLC. Neither the plaintiffs nor the other minority limited partners had the right to continued ownership in MRI, LLC. To the contrary, Via Christi's whole purpose in orchestrating the merger centered on the elimination of the other limited partners' ownership rights in MR Imaging Center. Thus, the plaintiffs received cash for their shares while Via Christi received cash plus continued ownership in the surviving entity, MRI, LLC. As a consequence, self-dealing existed. The plaintiffs carried their burden of establishing self-dealing in the transaction.

With the burden shifted, Via Christi could have validated the transaction by establishing either that a fair price was paid for the plaintiffs' interest or that all of the disinterested partners approved the transaction. The second way of validating the transaction could not have been shown because all of the disinterested partners did not approve the merger. Nor could Via Christi use Weinberger to shift the burden back to the plaintiffs and employ Weinberger's heightened requirement, because appraisal rights did not exist for the plaintiffs. Therefore, Via Christi's only available alternative should have been demonstrating that the plaintiffs received a fair price for their cashed-out shares. 


\section{CONCLUSION}

The plaintiffs in Welch v. Via Christi Health Partners, Inc. sought to utilize the two protective devices normally employed in corporate squeeze-out mergers to guarantee a fair price for their cashed-out shares. The first device failed because no statute granting appraisal rights applied to the merger. The second device, damages stemming from a breach of fiduciary duty, also failed to yield a judicially-determined fair price, but only because the Kansas Supreme Court misconstrued statutory provisions and misapplied corporate case law.

A correct fiduciary duty analysis reveals that limited partners in a squeeze-out merger will always be guaranteed a judicially-determined fair merger price for their cashed-out shares. Via Christi engaged in selfdealing, an action prohibited by section 404(b)(2) of KUPA. As a result, Via Christi should have been required to demonstrate a fair merger price to avoid breaching its fiduciary duty to the limited partners. The heightened burden in Weinberger did not apply to the transaction because a judicially-determined fair merger price was not ensured through appraisal rights.

The court's fiduciary duty analysis in Welch must be revisited to protect minority interest holders in non-corporate entities. Welch allows majority interest holders more leeway to cleverly craft squeeze-out mergers in an effort to evade the protections afforded by a judiciallydetermined merger price. Until Welch is overturned, minority interest holders in non-corporate entities face the increasing chance of finding themselves up squeeze-out merger creek without a paddle. 